\title{
QUANTITATIVE PARAMETERS OF FLORAL STEMS OF GLADIOLUS PLANTS GROWN UNDER MINIMUM TILLAGE SYSTEM IN SANTA CATARINA, BRAZIL $^{1}$
}

\author{
LEOSANE CRISTINA BOSCO ${ }^{2}$, LUCIANE TEIXEIRA STANCK ${ }^{2}$, ALEXANDRA GOEDE DE SOUZA $^{3}$, \\ OTAVIO BAGIOTTO ROSSATO ${ }^{4}$, LILIAN OSMARI UHLMANN ${ }^{5}$, NEREU AUGUSTO STRECK ${ }^{5}$
}

\begin{abstract}
The objective of this work was to characterize the commercial quantitative standards of floral stems of gladiolus plants grown under minimum tillage and conventional systems in two harvest seasons in the state of Santa Catarina, Brazil. Experiments were conducted in locations with subtropical climate using soils classified as Typic Dystrudept (Cambissolo) and Typic Hapludox (Nitossolo). Gladiolus plants were grown in beds with intensive soil turning, and under minimum tillage system, in which soil turning was done only in the planting rows. Plants of the cultivars Red Beauty and White Goddess were evaluated in two harvest seasons, Mothers' Day, and Valentine's Day. A completely randomized experimental design with 12 replications was used; the treatments consisted of two harvest seasons and two soil management systems. The flower stem and inflorescence lengths, stem thickness, and number of florets were measured when the plants were at the harvest point to characterize their commercial quantitative standards. These data were used to distribute the stems into four classes $(75,90,110$ and non-marketable). The stem standard of gladiolus plants grown under minimum tillage system and the edaphoclimatic conditions of the state of Santa Catarina in the Mother's Day harvest met the flower market requirements, with most stems classified into the classes 90 and 110. Therefore, gladiolus plants can be grown under minimum tillage system without affecting the flower stem development. This work is the first step to promote the growth of flowers under a conservationist perspective, focused on a more sustainable agriculture.
\end{abstract}

Keywords: Gladiolus x grandiflorus Hort. Soil conservation. Subtropical climate.

\section{PARÂMETROS QUANTITATIVOS DE HASTES FLORAIS DE GLADÍOLO EM SISTEMA DE CULTIVO MÍNIMO DO SOLO EM SANTA CATARINA}

RESUMO - O objetivo do trabalho foi caracterizar o padrão comercial quantitativo de hastes florais de gladíolo produzidas no sistema de cultivo mínimo e convencional do solo em duas épocas de colheita em Santa Catarina. Foram realizados experimentos em locais com clima subtropical e solos classificados como Cambissolo e Nitossolo. O gladíolo foi produzido em canteiros com revolvimento intensivo do solo e, em cultivo mínimo, no qual o revolvimento do solo foi realizado apenas nas linhas de plantio sobre palhada. As cultivares utilizadas foram Red Beauty e White Goddess em duas épocas de colheita, Dia das Mães e Namorados. O delineamento experimental foi inteiramente casualizado com 12 repetições, sendo os tratamentos: duas épocas de colheita e dois sistemas de manejo do solo. Quando as hastes florais estavam em ponto de colheita realizaram-se as medidas para caracterização dos padrões quantitativos: comprimento total da haste e da espiga, espessura da haste e o número de floretes. Com base nesses dados, as hastes foram distribuídas nas classes 75, 90, 110 e não comercializável. O padrão das hastes de gladíolo produzidas em sistema de cultivo mínimo em condições edafoclimáticas de SC para colheita no Dia das Mães cumpriu as exigências do mercado de flores, sendo a maioria das hastes classificadas como 90 e 110. Portanto, o gladíolo pode ser produzido em sistema de cultivo mínimo sem comprometer o padrão das hastes florais. Esse é o primeiro passo para o incentivo de cultivo de flores sob um olhar conservacionista, de modo a orientarmos cultivos agrícolas mais sustentáveis.

Palavras-chave: Gladiolus x grandiflorus Hort. Conservação do solo. Clima subtropical.

\footnotetext{
${ }^{*}$ Corresponding author

${ }^{1}$ Received for publication in 05/06/2020; accepted in 01/29/2021.

Paper extracted from the Master's dissertation of the second author.

${ }^{2}$ Department of Agriculture, Biodiversity and Forest, Universidade Federal de Santa Catarina, Curitibanos, SC, Brazil; leosane.bosco@ufsc.br - ORCID: 0000-0003-2623-2590, luciane.teixeira@posgrad.ufsc.br - ORCID: 0000-0002-6563-4210.

${ }^{3}$ Instituto Federal catarinense, Rio do Sul, SC, Brazil; alexandra.souza@ifc.edu.br - ORCID: 0000-0002-0572-0205.

${ }^{4}$ Instituto Federal catarinense, Concórdia, SC, Brazil; otavio.rossato@ifc.edu.br - ORCID: 0000-0003-4877-9255.

${ }^{5}$ Department of Phytotechnics, Universidade Federal de Santa Maria, Santa Maria, RS, Brazil; uhlmannlilian@gmail.com - ORCID: 0000-0001-9142-4201,nstreck2@yahoo.com.br - ORCID: 0000-0002-2495-0823.
} 


\section{INTRODUCTION}

Sustainable agriculture is focused on the natural ecosystems as a model to promote diversity and stability of agricultural production systems. The diversification of species and maintenance of the soil cover in rural properties are among the practices used to develop more sustainable agricultural systems (OUMA; JERUTO, 2010; WANI et al., 2018).

Incentives to produce gladiolus plants (Gladiolus $x$ grandiflorus Hort.) in the South of Brazil emerged from the need for increasing agricultural diversity in family farms (SCHWAB et al., 2019; UHLMANN et al., 2019). However, this production requires information on soil management systems that are more sustainable than those currently practiced. The current practices adopted include intensive soil turning for preparation of beds, which intensify erosion, reduce soil organic matter by accelerating oxidation and decrease the soil capacity to supply water and nutrient to plants (NARESH et al., 2013; WANI et al., 2018). This soil preparation system increases soil losses by erosion, mainly in regions with steep slopes or irregular reliefs, as the case of most rural properties in the state of Santa Catarina, Brazil.

Conventional tillage system using beds is commonly practiced for the growth of gladiolus plants, which is a flower species widely distributed in Brazil and has a high socioeconomic importance (SCHWAB et al., 2019). Gladiolus plants are commercially grown in Santa Catarina by farmers in the Highland, and Upper Itajaí River Valley regions (SCHWAB et al., 2019). Gladiolus are rustic plants propagated by corms or bulbs that presents easy and low-cost growth, short cycle, easy management, added value, and fast financial return (SCHWAB et al., 2019). In addition, it has a large potential for flower and bulb production in small areas, making it an alternative for the diversification and income in small family farms (SCHWAB et al., 2019; UHLMANN et al., 2019).

This flower has been studied in the South region of Brazil for approximately 10 years; thus, its growth and development characteristics when grown in beds is widely known (SCHWAB et al., 2015; SCHWAB et al., 2017; UHLMANN et al., 2017; SCHWAB et al., 2018; TOMIOZZO et al., 2018; UHLMANN et al., 2019; TOMIOZZO et al., 2019; BECKER et al., 2020). However, problems in management practices for gladiolus plants persist and need to be adjusted, including those related to the intensive soil use.

Studies have shown several conservationists advances in Brazilian agriculture with implementation of minimum tillage system, notillage system with direct planting on crop residues and, more recently, vegetable no-tillage system (FAYAD et al., 2019). Considering these conservationist experiments, the growth of gladiolus plants without soil turning and with permanent soil cover have potential to decrease soil erosion and, consequently, production costs, and the use of machinery to raising beds. Studies have also shown that the maintenance of soil cover allows plant residues to act as insulating of soil over time, reduce soil thermal amplitude, increase organic matter accumulation, maintain soil moisture, promote ecosystem services, and improve soil structure (MATHEW et al., 2012; PIRES et al., 2017; DRAKOPOULOS; SCHOLBERG; LANTINGA, 2018). In addition, minimum tillage system assists in weed control, decreasing labor demand, and in soil water conservation, decreasing irrigation costs (SOUZA et al., 2013; KIELING et al., 2009). These are benefits for farmers and consumers, due to decreases in environmental and production costs and maintenance or increases in yield and quality of plants.

Gladiolus plants are plants that participate in short marketing cycles, in the context of family farms (UHLMANN et al., 2019), and is starting to be grown in organic and conservationist systems. Experiments conducted in the South region of Brazil are the based for the development of the hypothesis that gladiolus plants can be grown under minimum tillage system without affecting the quality of floral stems. The confirmation of this hypothesis by scientific experiments is the first step to develop a conservationist view to flower productions and encourage the development of more specific researches on soil quality for gladiolus plants.

Therefore, the objective of this work was to characterize the commercial quantitative standards for floral stems of gladiolus plants grown under minimum tillage and conventional systems in two harvest seasons in the state of Santa Catarina, Brazil, focused on improving the sustainability of the tillage system for gladiolus plants.

\section{MATERIAL AND METHODS}

\section{Characterization of the experimental areas}

Field experiments were conducted in three locations of the state of Santa Catarina, Brazil, which are representative of three agroecological zones: Rio do Peixe River Valley and Central Highlands (Curitibanos), Upper Itajaí River Valley (Rio do Sul), and Uruguay River Valley (Concórdia) (THOMÉ et al., 1999). The geographical and edaphoclimatic characterization of each site is shown in Table 1. 
L. C. BOSCO et al.

Table 1. Geographical, climatic, and edaphic characteristics of experimental sites for gladiolus plants (Gladiolus $x$ grandiflorus Hort.) grown under minimum tillage and conventional tillage systems in the state of Santa Catarina, Brazil.

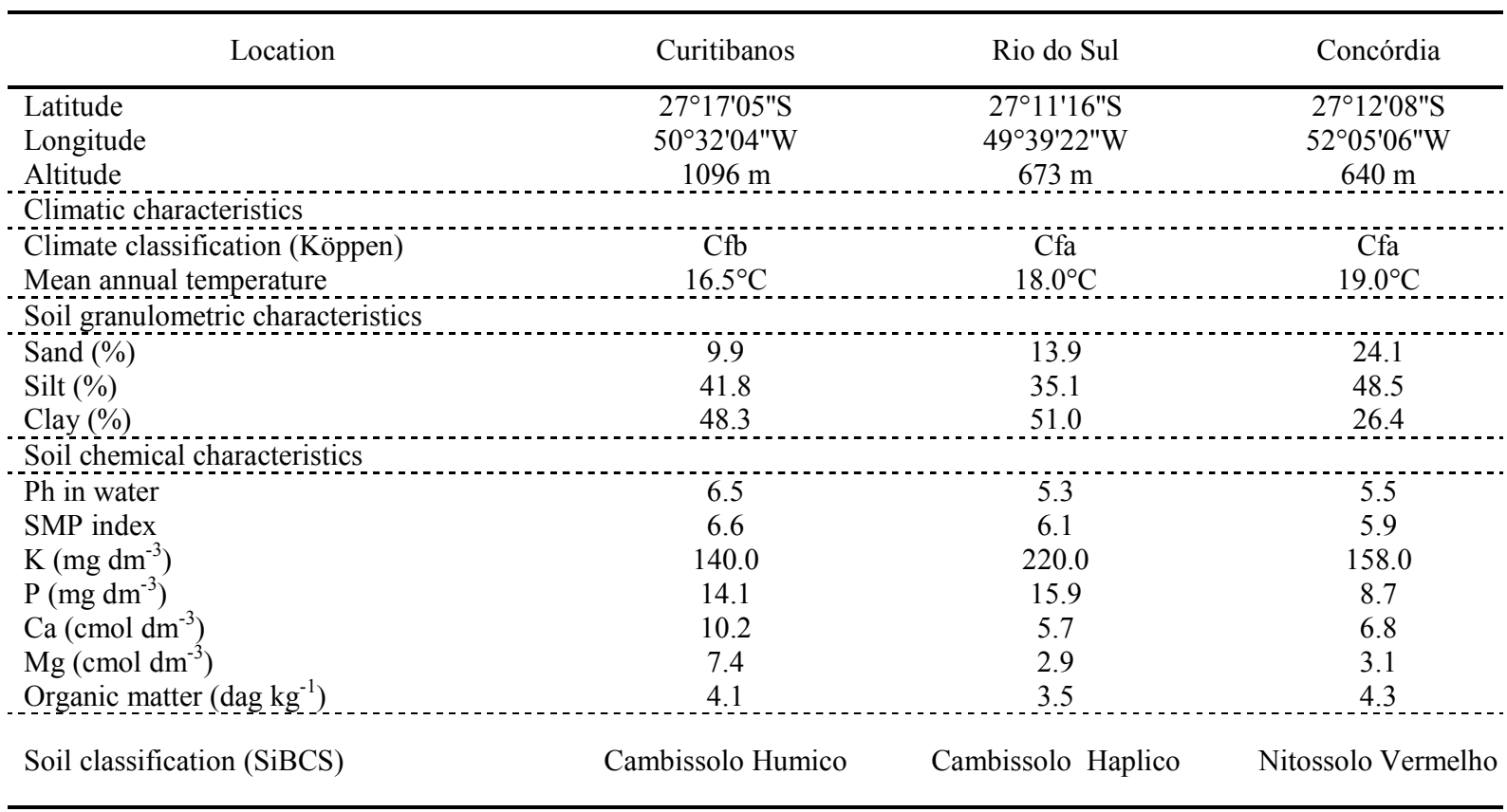

Sources: Alvares et al. (2013); Embrapa (2011); Santos et al. (2018).

\section{Design experimental}

A completely randomized experimental design was used to evaluate the floral stem quality of gladiolus plants, with two factors. Factor A consisted of two tillage systems (conventional and minimum) and factor B consisted of two harvest seasons (Mothers' Day and Valentine's Day). Each treatment consisted of twelve replications, and each replication consisted of one plant in the central area of the corresponding bed of each treatment. The borders of the beds were formed by 22 plants in each end.

\section{Tillage systems}

Gladiolus plants were grown under two tillage systems, conventional and minimum tillage systems. The conventional system consisted of beds prepared using a subsoiler, followed by two turns of a motocultivator to raise the beds, i.e., with intensive soil turning; the beds were $10 \mathrm{~m}$ length and $1 \mathrm{~m}$ width. The minimum tillage system had been implemented two years before the experiment in areas used for conventional tillage (Rio do Sul and Concórdia) or fallow areas (Curitibanos). Millet (Pennisetum glaucum) plants had been used as soil cover plants before the planting of gladiolus plants. These plants were desiccated, generating approximately $5 \mathrm{Mg} \mathrm{ha}^{-1}$ of dry matter. Planting furrows with approximately $15 \mathrm{~cm}$ depth were manually opened on the plant residues.

\section{Harvest seasons}

The gladiolus plants used were from the cultivars Red Beauty, which form red flowers, and White Goddess, which form white flowers; both have intermediate II cycle (BECKER et al., 2020) and are cultivars with high market demand and long pot life.

The planting date defined for both cultivars was based on the PhenoGlad model (UHLMANN et al., 2017), which includes air temperature data to calculate the development of gladiolus plants, focused on the harvest in two specific seasons of the year. Season 1 had flowers harvested for the Mothers' Day season, which is at the second Sunday of May; in this case, the planting dates were February 12, 15, and 19, 2018 for Curitibanos, Concórdia, and Rio do Sul, respectively. Season 2 had flowers harvested for Valentine's Day season (June 12); the planting dates were March 03, 08, and 09, 2018 for Curitibanos, Concórdia, and Rio do Sul, respectively. The planting dates were different in the locations within each season due to the different thermal availability, but the harvest season was the same (UHLMANN et al., 2017).

\section{Management practices}

Gladiolus plants were propagated from healthy vernalized corms of the $12 / 14$ class, i.e., that had 12 to $14 \mathrm{~cm}$ circumference. The corms were 
planted to a depth of approximate $10 \mathrm{~cm}$ in $10 \mathrm{~m}$ parallel rows spaced $40 \mathrm{~cm}$ apart with $20 \mathrm{~cm}$ between plants, in both tillage systems. The beds were irrigated during the experimental period using a drip system and the plants were trellised with raffia wires.

Fertilizers were applied at planting, and as topdressing when the plants were at the third visible leaf stage (V3), according to interpretation of the soil analysis, adapted from recommendations for ornamental plants in the RS and SC (CQFS, 2016). The fertilizer rates used at planting were $55 \mathrm{~kg} \mathrm{ha}^{-1}$ of urea, $217 \mathrm{~kg} \mathrm{ha}^{-1}$ of triple superphosphate, and 200 $\mathrm{kg} \mathrm{ha}^{-1}$ of potassium chloride, and the rates used as topdressing were $130 \mathrm{~kg} \mathrm{ha}^{-1}$ of urea and $130 \mathrm{~kg} \mathrm{ha}^{-1}$ of $\mathrm{KCl}$.

\section{Climatic variables}

The minimum and maximum daily air temperature were measured during the development of the plants in the three experimental areas, using an automatic weather station (Vantage Pro2TM, Davis Instruments) with data recorded hourly. Soil temperature measurements were obtained using analog geothermometers only for Curitibanos (winter of 2017 and autumn of 2019) and Concórdia (spring of 2018 and autumn of 2019) for parallel studies involving the two tillage systems for gladiolus plants. The geothermometers were installed in the planting rows at depths of 5 and $10 \mathrm{~cm}$. The temperatures were measured daily at 9:00h and 15:00h. The soil temperature was measured hourly for 24 hours, in clear days to analyze the soil temperature variation curve over the day. The soil temperatures found were evaluated as a case study, since they were not specifically measured for the present experiments.

\section{Quantitative parameters of floral stems}

Quantitative aspects of floral stems were evaluated in 12 plants of each treatment. The total stem length from the plant base to the inflorescence tip, inflorescence length from the first floret insertion to the inflorescence tip, and stem thickness at the first floret insertion height were measured. These measurements were carried out when the floral stems were at the harvest point, at the R2 stage, i.e., first three floral buttons at the lower part of the inflorescence showing the characteristic color, at approximately 90 days after the planting. The results were used to classify the plants according to the quality standard established by Holambra (2013). The number of florets in each inflorescences of the plants was also evaluated; it was quantified during the floret opening stage.
The quantitative standards for floral stem analysis of gladiolus plants were used to classify the plants into the classes: 75 (stem length of $75 \mathrm{~cm}$ ); 90 (stem length of $90 \mathrm{~cm}$ ); and 110 (stem length of $110 \mathrm{~cm}$ ). The stem thickness of the plants was classified considering the stem length into the classes 75 (minimum thickness of $0.5 \mathrm{~cm}$ ); 90 (minimum thickness of $0.8 \mathrm{~cm}$ ); and 110 (minimum thickness of $1.0 \mathrm{~cm}$ ). The inflorescence length should have at least $40 \%$ of the total stem length; therefore, stems with lengths lower than $75 \mathrm{~cm}$, with inflorescence proportion lower than $40 \%$ of the total stem length and/or did not meet the minimum diameter criteria or stem length were classified as non-marketable plants.

\section{Statistical analyses}

Statistical analyses were carried out considering the two sources of variation (systems and harvest seasons), separately for each cultivar and site, since it was assumed the existence of genotypical and climatic differences, and the main objective of this work was to identify the effects of the tillage systems and harvest seasons on the quality of the floral stems.

Tests for normality and homogeneity of variance of the data were applied, and transformations were done when required. The analysis of variance was carried out using the Tukey's test to identify statistical differences between the treatments at 5\% probability level of error. The statistical analyses were done using the $\mathrm{R}$ programming language.

\section{RESULTS AND DISCUSSIONS}

\section{Climatic conditions}

The maximum absolute air temperatures found in the experimental periods for harvests at Seasons 1 (Mothers' Day) and 2 (Valentine's Day) were of $29.8^{\circ} \mathrm{C}$ in Curitibanos, $33.3^{\circ} \mathrm{C}$ in Concórdia, and $34.4^{\circ} \mathrm{C}$ in Rio do Sul. The minimum absolute air temperature found for Season 1 was $1.3^{\circ} \mathrm{C}, 2.7^{\circ} \mathrm{C}$, and $6.0^{\circ} \mathrm{C}$, and for season 2 was $0.3^{\circ} \mathrm{C}, 0.9^{\circ} \mathrm{C}$, and $3.5^{\circ} \mathrm{C}$ for Curitibanos, Concórdia, and Rio do Sul, respectively (Figure 1). The minimum air temperatures in Season 1, which last several days, were lower than $15^{\circ} \mathrm{C}$, mainly by the end of the plant cycle. Temperatures lower than $15^{\circ} \mathrm{C}$ were found in Curitibanos for 69 days, in Concórdia for 27 days, and in Rio do Sul for 36 days. According to Severino (2007), these temperatures are below those ideal for gladiolus plants and states that the temperatures should be between $20^{\circ} \mathrm{C}$ and $25^{\circ} \mathrm{C}$ during the plant 
cycle for an adequate development of the plants. However, despite the temperatures were below the ideal range, no symptoms of cold stress were found in plants grown in Season 1. According to Schwab et al. (2018), only extreme temperatures (above $35^{\circ} \mathrm{C}$ and below $0^{\circ} \mathrm{C}$ ) decreased the commercial quality of stems of plants grown in the South region of Brazil.The air temperatures were even lower in Season 2, the lowest temperatures from May to June were lower than $10^{\circ} \mathrm{C}$ for 30 days in Curitibanos, 22 days in Concórdia, and 18 days in Rio do Sul (Figure 1). The lowest temperatures close to the harvest season were lower than $5^{\circ} \mathrm{C}$ in Curitibanos, which are below of lowest temperature at the reproductive stage, which was $6^{\circ} \mathrm{C}$ (SCHWAB et al., 2017; UHLMANN et al., 2017). Nine frost occurrences were observed in this period, which froze the florets, stopping their development, and caused reddening symptoms in the sepals of the floral stems, resulting in a negative quantitative effect on the stems (Figure $3)$. In a study conducted in the Central Depression Region of the state of Rio Grande do Sul, Brazil, which has a Cfa climate, gladiolus plants that were at the reproductive stage in early June, were also damaged by frost events, making the stems unsuitable for marketing (SCHWAB et al., 2018). Considering these risks of frost events in Santa Catarina, studies have recommended to avoid the growth of flowers intended for marketing at Valentine's Day season in the Rio do Peixe River Valley and Central Highland regions, in Curitibanos, to decrease the occurrence of damages to the floral stems (BONATTO, 2019).

The mean soil temperature at $5 \mathrm{~cm}$ depth, measured for 24 hours, was $7.2 \%$ higher in the conventional than in the minimum tillage system (Figure 2A). The lowest soil temperature in the daily evaluations was $1.7 \%$ higher (Figure $2 \mathrm{C}$ ), the highest temperature was 5.9\% lower (Figure 2D), and the thermal amplitude was $10.3 \%$ lower (Figure $2 \mathrm{~B}$ ) in the minimum tillage system, when compared to the conventional tillage system. The highest temperatures found at $5 \mathrm{~cm}$ depth varied more between systems than the lowest, modifying the soil thermal amplitude.

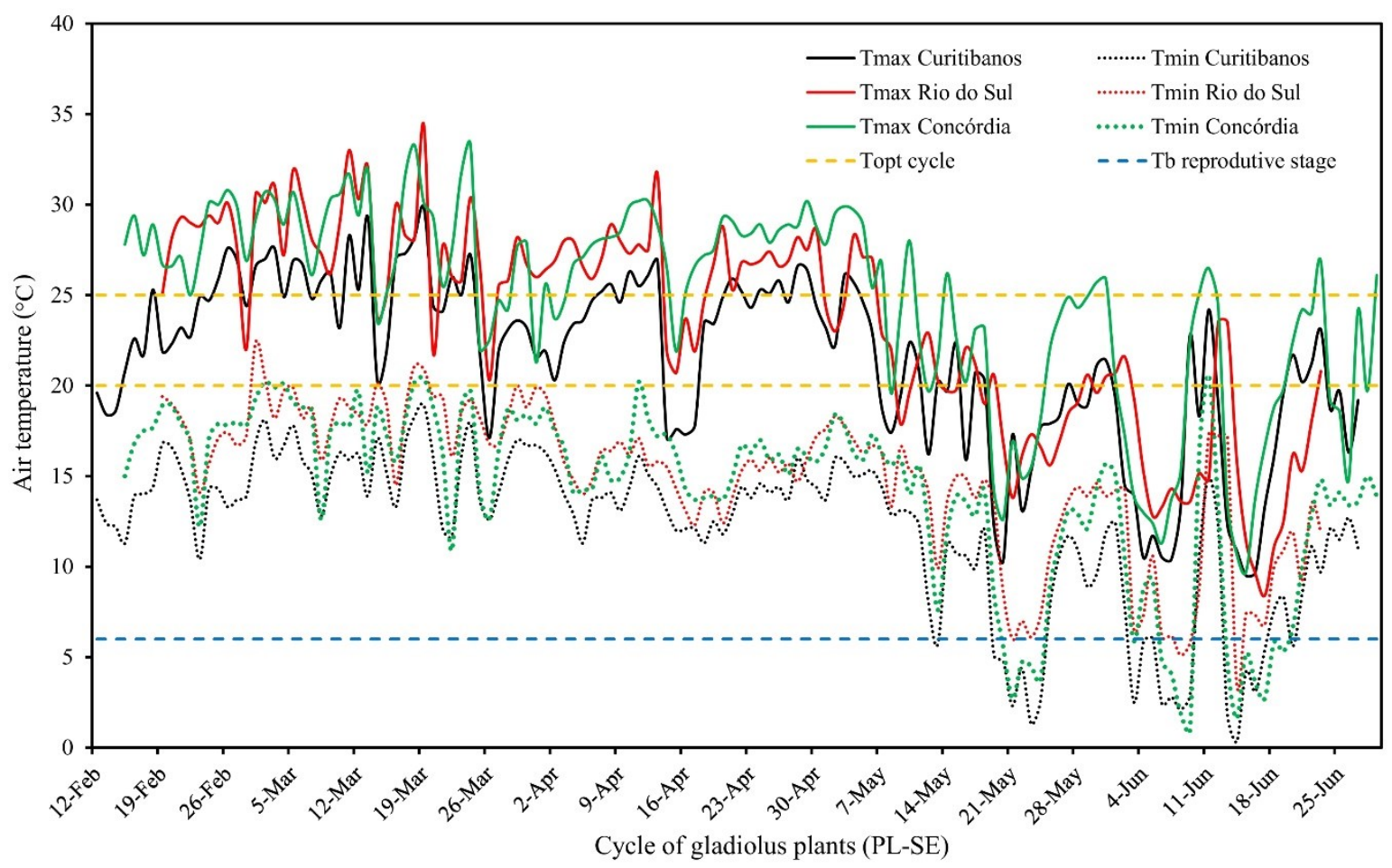

Yellow horizontal lines represent the ideal temperature range - Topt $\left(20\right.$ to $\left.25^{\circ} \mathrm{C}\right)$ and blue lines represent the base temperature at the reproductive stage $-\mathrm{Tb}\left(6^{\circ} \mathrm{C}\right)$ of gladiolus plants.

Figure 1. Daily minimum (Tmin) and maximum (Tmax) air temperatures during the cycle of gladiolus plants (Gladiolus $x$ grandiflorus Hort.) from the planting to the stem senescence stage (PL-SE), for two harvest seasons (Mothers' Day and Valentine's Day of 2018), in Curitibanos, Rio do Sul, and Concórdia, Santa Catarina, Brazil. 

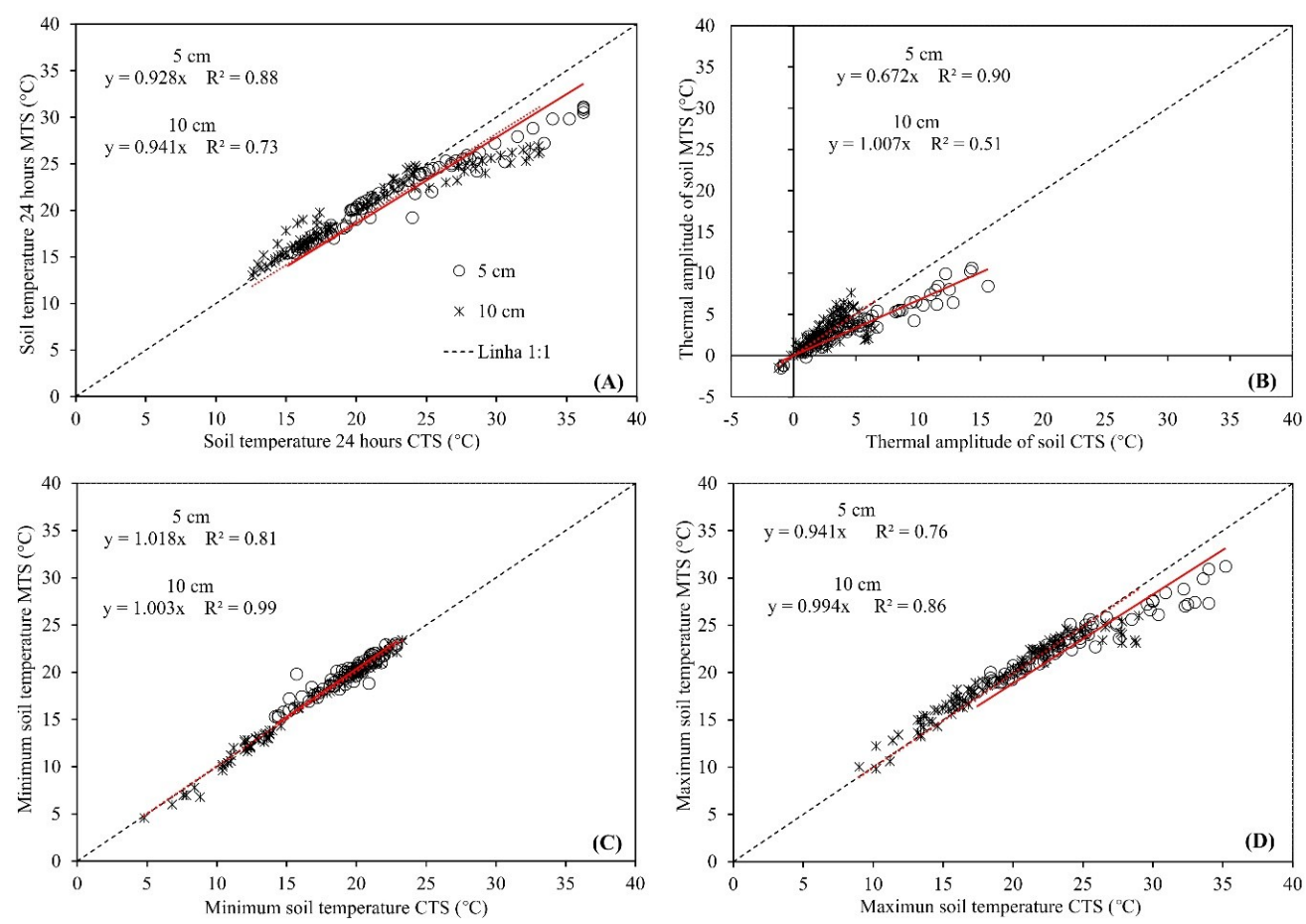

Figure 2. Soil temperature measured for 24 hours (A), thermal amplitude (B), and minimum (C) and maximum (D) soil temperatures measured daily in Curitibanos (winter of 2017 and autumn of 2019) and Concórdia (spring of 2018 and autumn of 2019), in soils with gladiolus plants (Gladiolus $x$ grandiflorus Hort.) grown under minimum tillage system (MTS) and conventional tillage system (CTS).

The mean soil temperature at $10 \mathrm{~cm}$ of depth measured for 24 hours in the conventional tillage system was $5.9 \%$ higher than that in the minimum tillage system (Figure 2A). However, the daily evaluations at $10 \mathrm{~cm}$ depth showed no differences between these systems. Gladiolus bulbs are recommended to be planted at $10 \mathrm{~cm}$ depth (SCHWAB et al., 2019), therefore, the soil temperature at this depth determines the plant population uniformity and, consequently, the homogeneity of the plant cycle. The homogeneity of soil temperatures between the tillage systems at 10 $\mathrm{cm}$ depth is consistent with the results found by
Stanck et al. (2019), who found no differences in time from the planting to emergence between minimum and conventional tillage systems.

\section{Quantitative parameters of floral stems of gladiolus plants of the cultivar Red Beauty}

The stem length (SL), inflorescence length (IL), stem thickness (ST), and number of florets (NF) were affected by the tillage systems and harvest season, but differently for each site and cultivar (Table 2).

Table 2. Stem length (SL), inflorescence length (IL), stem thickness (ST), and number of florets (NF) in gladiolus plants (Gladiolus $x$ grandiflorus Hort.) of the cultivar Red Beauty grown for different harvest seasons [Mothers' Day (T1) and Valentine's Day (T2)], under conventional (CTS) and minimum (MTS) tillage systems and edaphoclimatic conditions of Curitibanos, Rio do Sul, and Concórdia, state of Santa Catarina, Brazil.

\begin{tabular}{|c|c|c|c|c|c|c|c|c|}
\hline \multirow{2}{*}{ Tillage System } & \multicolumn{2}{|c|}{$\overline{S L}$} & \multicolumn{2}{|c|}{ IL } & \multicolumn{2}{|c|}{ ST } & \multicolumn{2}{|c|}{ NF } \\
\hline & T1 & $\mathrm{T} 2$ & T1 & $\mathrm{T} 2$ & T1 & $\mathrm{T} 2$ & $\mathrm{~T} 1$ & $\mathrm{~T} 2$ \\
\hline \multicolumn{9}{|c|}{ Curitibanos } \\
\hline CTS & $86 \mathrm{Bb}^{--}$ & $103 \mathrm{Ab}$ & $36 \mathrm{Aa}$ & $42 \mathrm{Aa}$ & $0.7 \mathrm{Ba}$ & $0.9 \mathrm{Aa}$ & 12 & $13^{\circ}$ \\
\hline MTS & $100 \mathrm{Ba}$ & $112 \mathrm{Aa}$ & $42 \mathrm{Aa}$ & $43 \mathrm{Aa}$ & $0.8 \mathrm{Ba}$ & $1.0 \mathrm{Aa}$ & 14. & 14. \\
\hline \multicolumn{9}{|c|}{ Rio do Sul } \\
\hline $\mathrm{CTS}$ & $80 \mathrm{Bb}$ & $103 \mathrm{Aa}$ & $55 \mathrm{~A}$ & $58 \mathrm{Aa}$ & $1.0 \mathrm{Bb}$ & $1.5 \mathrm{Aa}$ & $10 \mathrm{Aa}$ & $12 \mathrm{~A} \bar{b}$ \\
\hline MTS & $102 \mathrm{Aa}$ & $103 \mathrm{Aa}$ & $68 \mathrm{Aa}$ & $54 \mathrm{Ba}$ & 1.3Aa & $1.4 \mathrm{Aa}$ & $11 \mathrm{Ba}$ & $15 \mathrm{Aa}$ \\
\hline \multicolumn{9}{|c|}{ Concórdia } \\
\hline $\mathrm{CTS}^{-}$ & $92 \mathrm{Ba}$ & $103 \mathrm{Aa}$ & $45 \mathrm{Ba}$ & $56 \mathrm{Aa}$ & $0.8^{-}$ & $0.8^{-1}$ & 13 & 12 \\
\hline MTS & $97 \mathrm{Aa}$ & $94 \mathrm{Ab}$ & $48 \mathrm{Aa}$ & $48 \mathrm{Aa}$ & 0.8 & 0.8 & 13 & 13 \\
\hline
\end{tabular}

Means followed by same uppercase letters in the rows (harvest seasons) or lowercase letters in the columns (tillage systems) are not different by the Tukey's test $(\alpha=5 \%)$. Means with absence of letters were not significant. 
The highest SL was found for the minimum tillage system in Season 2 in Curitibanos, and the lowest for the conventional tillage system in Season 1 in Rio do Sul, which presented no difference between tillage systems in Season 2. The highest SL in Concórdia was found for the conventional tillage system in Season 2, with no difference between tillage systems in Season 1 (Table 2).

The IL presented no significant differences between systems or harvest seasons in Curitibanos. The IL was higher for the minimum tillage system in Season 1 in Rio do Sul, with no difference between tillage systems in Season 2. Plants grown in Concórdia presented higher IL in Season 2, also with no difference between tillage systems.

The ST varied as function of harvest seasons in Curitibanos and Rio do Sul and was higher in Season 2. Plants grown in Concórdia presented no significant differences in ST between systems or harvest seasons.

The analysis of variance showed that the number of florets (NF) in Curitibanos and Concórdia was not affected by the tillage systems, harvest seasons or by the interaction between them. However, Rio do Sul presented significantly higher $\mathrm{NF}$ in the minimum tillage system in Season 2
(Table 2).

In Curitibanos, approximately of $75 \%$ of the stems of Red Beauty plants were classified as 75 and 90 (Figure 3A). The mean percentage of floral stems classified as non-marketable (NM) in Curitibanos was $33.5 \%$ in the conventional, and $50 \%$ in minimum tillage system. However, approximately $75 \%$ of stems of plants grown under minimum tillage system in Season 2 were declassified due to the low temperatures.

In Rio do Sul, $77 \%$ of stems were classified as 75 and 90, and the mean percentage of floral NM stems was $16.5 \%$ in the conventional, and $0 \%$ in the minimum tillage system (Figure 3A).

In Concórdia, $94 \%$ of the stems were classified as 75 and 90, and the mean percentage of NM floral stems was $4 \%$ in both tillage systems (Figure 3A).

\section{Quantitative parameters of floral stems of plants of the cultivar White Goddess}

The SL, IL, ST, and NF of plants of the cultivar White Goddess were affected by the tillage system and harvest seasons, but differently for each site and cultivar (Table 3 ).

Table 3. Stem length (SL), inflorescence length (IL), stem thickness (ST), and number of florets (NF) in plants of the cultivar White Goddess grown for different harvest seasons [Mothers' Day (T1) and Valentine's Day (T2)], under conventional (CTS) and minimum (MTS) tillage systems and edaphoclimatic conditions of Curitibanos, Rio do Sul, and Concórdia, state of Santa Catarina, Brazil.

\begin{tabular}{|c|c|c|c|c|c|c|c|c|}
\hline \multirow{2}{*}{ Tillage System } & \multicolumn{2}{|c|}{ SL } & \multicolumn{2}{|c|}{ IL } & \multicolumn{2}{|c|}{ ST } & \multicolumn{2}{|c|}{$\mathrm{NF}$} \\
\hline & $\mathrm{T} 1$ & $\mathrm{~T} 2$ & $\mathrm{~T} 1$ & $\mathrm{~T} 2$ & $\mathrm{~T} 1$ & $\mathrm{~T} 2$ & $\mathrm{~T} 1$ & $\mathrm{~T} 2$ \\
\hline \multicolumn{9}{|c|}{ Curitibanos } \\
\hline $\mathrm{CTS}$ & $130 \mathrm{Aa}$ & $136 \mathrm{Aa}$ & $56 \mathrm{Aa}$ & $48 \mathrm{Bb}$ & $1.0 \mathrm{Aa}$ & $1.0 \mathrm{Aa}$ & 17 & 17 \\
\hline MTS & $119 \mathrm{Bb}$ & $136 \mathrm{Aa}$ & $49 \mathrm{Bb}$ & $57 \mathrm{Aa}$ & $0.9 \mathrm{Ba}$ & $1.0 \mathrm{Aa}$ & 16 & 17 \\
\hline \multicolumn{9}{|c|}{ Rio do Sul } \\
\hline $\mathrm{CTS}$ & $108 \mathrm{Bb}$ & $116 \mathrm{Aa}$ & $68 \mathrm{Ab}$ & $66 \mathrm{Aa}$ & $1.5 \mathrm{Bb}$ & $1.8 \mathrm{Aa}$ & $16^{-}$ & $16^{-1}$ \\
\hline MTS & $127 \mathrm{Aa}$ & $121 \mathrm{Aa}$ & $82 \mathrm{Aa}$ & $69 \mathrm{Ba}$ & $1.9 \mathrm{Aa}$ & $1.8 \mathrm{Aa}$ & 15 & 16 \\
\hline \multicolumn{9}{|c|}{ Concórdia } \\
\hline $\mathrm{CTS}$ & $127^{-}$ & 131 & 66 & 73 & 0.9 & 0.9 & $20 \mathrm{Aa}$ & $17 \mathrm{Ba}$ \\
\hline MTS & 128 & 126 & 65 & 69 & 1.0 & 0.9 & $18 \mathrm{Aa}$ & $17 \mathrm{Aa}$ \\
\hline
\end{tabular}

Means followed by same uppercase letters in the rows (harvest seasons) or lowercase letters in the columns (tillage systems) are not different by the Tukey's test $(\alpha=5 \%)$. Means with absence of letters were not significant.

The lowest SL in Curitibanos was found for the minimum tillage system in Season 1, these differences were not found in Season 2. The lowest SL in Rio do Sul was found for the conventional tillage system in Season 1, and no differences were found between tillage systems in Season 2. The sources of variation had no effect on the SL in Concórdia (Table 3).

The highest IL of plants grown in Curitibanos were found for the conventional tillage system in Season 1, and for the minimum tillage system in Season 2 (Table 3). The highest IL of plants in Rio do Sul was found for the minimum tillage system in
Season 1, and no differences between tillage systems were found in Season 2. The sources of variation had no effect on the IL in Concórdia.

The ST of plants in Curitibanos varied only due to the harvest seasons and the stems presented lower thickness in Season 1 in the minimum tillage system. The ST of plants in Rio do Sul was significantly higher for the minimum tillage system in Season 1. No significant differences in ST were found between systems or harvest seasons in Concórdia.

The analysis of variance showed that the NF of plants of the cultivar White Goddess grown in 
Curitibanos and Rio do Sul was not affected by the tillage systems, harvest seasons or by interaction between them. The NF of plants grown in Concórdia was significantly higher in Season 1 for the conventional tillage system, but with no significant differences between systems (Table 3).

Approximately $52 \%$ of the stems of plants of the cultivar White Goddess grown in Curitibanos were classified as 90 and 100 (Figure 3B). The mean percentage of floral stems classified as NM in Curitibanos was $50 \%$ in the conventional, and $45.5 \%$ in the minimum tillage system. In Season 2, 75\% of stems from the conventional, and $58 \%$ of stems from the minimum tillage system were declassified due to low temperatures.

In Rio do Sul and Concórdia, on average, $75 \%$ of stems were classified as 100 , and no stems were classified as NM. Plants grown under minimum tillage system had $91 \%$ and $71 \%$ of stems reaching the 100 class in Rio do Sul and Concórdia, respectively (Figure $3 \mathrm{~B}$ ).
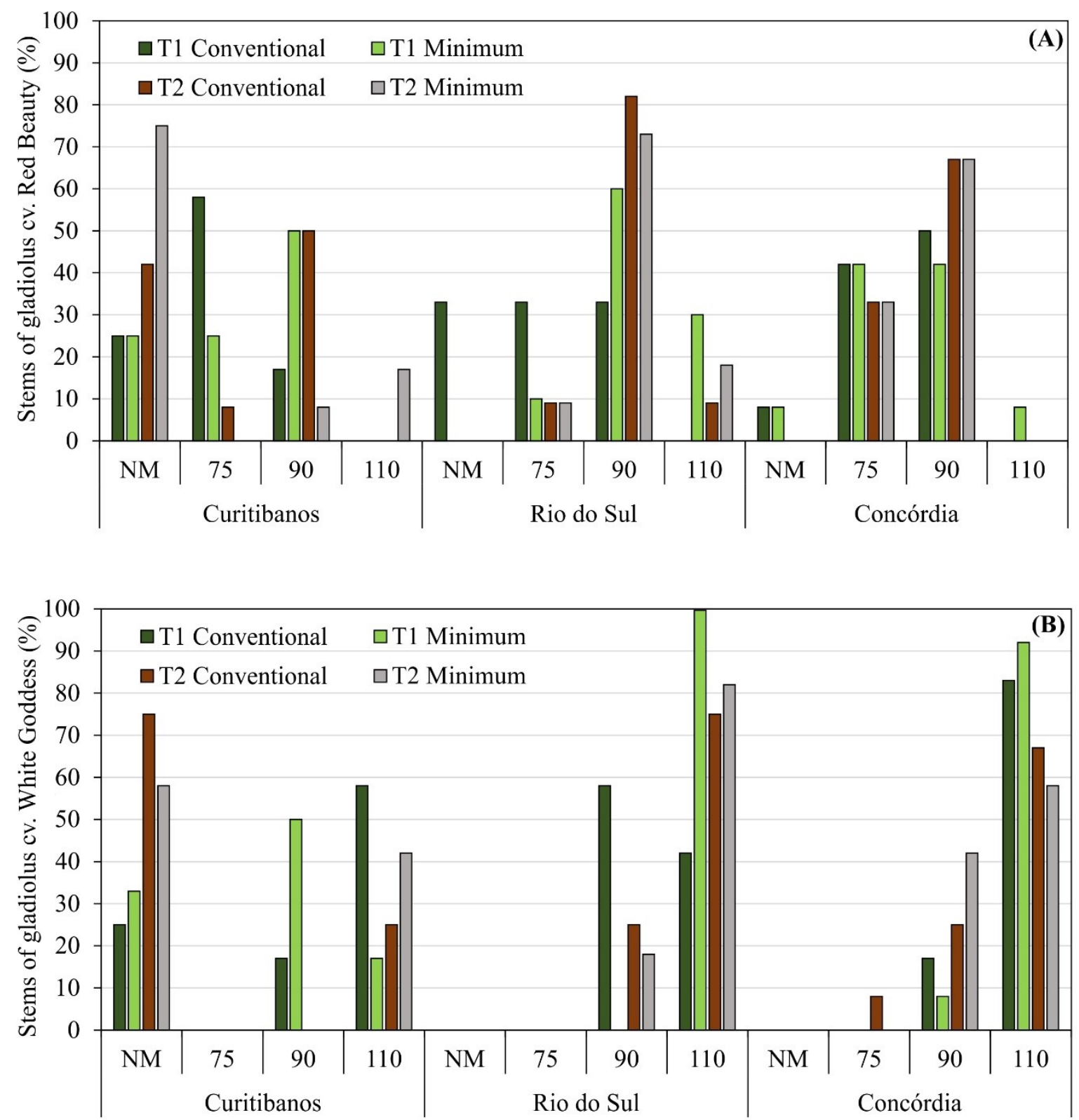

$\mathrm{NM}=$ non-marketable stems; $75=$ stems with $75 \mathrm{~cm}$ length; $90=$ stems with $90 \mathrm{~cm}$ length; $110=$ stem with $110 \mathrm{~cm}$ length.

Figure 3. Marketing classification of stems of gladiolus plants of the cultivars Red Beauty (A) and White Goddess (B) grown for different harvest seasons [Mothers' Day (T1) and Valentine's Day (T2)], under conventional and minimum tillage systems and edaphoclimatic conditions of Curitibanos, Rio do Sul, and Concórdia, state of Santa Catarina, Brazil. 
These results confirm that the planting time is important for the quantitative parameters of stems of gladiolus plants, since the conditions to which the plants are exposed affect these variables (ADIL et al., 2013; SCHWAB et al., 2015). Thus, following the guidelines for the best harvest seasons according to cultivar and site is recommended. The growth of plants of the Red Beauty and White Goddess cultivars for the Valentine's Day harvest season in Curitibanos is not recommended due to the high risk of losses by low temperatures.

The results found for the minimum, and conventional tillage systems did not show that one tillage system is more limiting or better than the other to produce stems that meet the commercial quantitative standards. Thus, the hypothesis that gladiolus plants can be grown under minimum tillage system without affecting the quality of floral stems was accepted. Studies on vegetable species, such as onion (SOUZA et al., 2013; LOSS et al., 2017), tomato (BRANCO et al., 2017), potato (DRAKOPOULOS; SCHOLBERG; LANTINGA, 2018), and chayote, squash, and Brassicaceae species, onion, tomato, Arracacia xanthorrhiza, and passion fruit (FAYAD et al., 2019) have also confirmed no, or small differences in yield and quality of these plants grown in conventional, and conservationist tillage systems. In addition, these studies have shown higher yields due improvements in the soil structure and functioning, soil-plant relations, and ecosystem services in conservationist soil tillage systems over time. Thus, these results obtained for the growth of gladiolus plants under minimum tillage system in the state of Santa Catarina are the first step towards the development of a conservationist view to flower productions, which promote more sustainable systems that associate the diversification of rural properties and maintenance of the soil cover.

\section{CONCLUSION}

Gladiolus plants can be grown under minimum tillage system in the municipalities of Curitibanos, Concórdia, and Rio do Sul, in the state of Santa Catarina, Brazil, without affecting the commercial quantitative standards of the floral stems. The experiments conducted in different regions of Santa Catarina showed the suitability of the region to produce gladiolus plants that present floral stems with high quantitative standards intended for marketing in the Mothers' Day harvest season.

\section{ACKNOWLEDGEMENTS}

The authors thank the contributors, scientific initiation students, laboratorists, field technicians, and drivers of the Federal University of Santa Catarina (UFSC), Federal University of Santa Maria (UFSM), Federal Institute of Santa Catarina of Concórdia and Rio do Sul (IFC) for the field technical support and transport during the experiments; and the ad hoc reviewers for the excellent suggestions for the improvement of this article.

\section{REFERENCES}

ADIL, M. et al. Effect of Different planting dates on growth and development of Gladiolus grandiflorus under the ecological conditions of Faisalabad, Pakistan. IJAVMS, 7: 94-107, 2013.

ALVARES, C. A. et al. Köppen's climate classification map for Brazil. Meteorologische Zeitschrift, 22: 711-728, 2013.

BECKER, C. et al. Scheduling optimum planting window for gladiola based on El Niño Southern Oscillation. Scientia Agricola, 77: e20180336, 2020.

BONATTO, M. I. Análise de riscos climáticos para o cultivo do gladíolo em Santa Catarina, Sul do Brasil. 2019. 103 f. Dissertação (Mestrado em Ciências: Área de Concentração em Manejo e Conservação de Ecossistemas Agrícolas e Naturais) Universidade Federal de Santa Catarina, Curitibanos, 2019.

BRANCO, R. B. F. et al. Nitrogen fertilization of vegetables cultivated under no-tillage after cover crops. Horticultura Brasileira, 35: 103-110, 2017.

CQFS - Comissão de Química e Fertilidade do Solo. Manual de calagem e adubação para os estados do Rio Grande do Sul e de Santa Catarina. 11. ed. Porto Alegre, RS: SBCS, 2016. 376 p.

DRAKOPOULOS, D.; SCHOLBERG, J. M. S.; LANTINGA, E. A. Influence of reduced tillage and fertilization regime on soil quality indicators in an organic potato production system. Biological Agriculture \& Horticulture, 34: 132-140, 2018.

EMBRAPA - Empresa Brasileira de Pesquisa Agropecuária. Atlas climático da Região Sul do Brasil: Estados do Paraná. Santa Catarina e Rio Grande do Sul. Editores técnicos: Wrege. M.S.; Steinmetz. S.; Reisser. J.C.; Almeida. I. R. Pelotas: Embrapa Clima Temperado; Colombo: Embrapa Florestas. 2011.

FAYAD, J. A. et al. Sistema de plantio direto de hortaliças: método de transição para um novo modo de produção. 1. ed. São Paulo, SP: Expressão 
Popular, 2019. 432 p.

HOLAMBRA, V. Critérios de classificação: gladíolo corte. 1. ed. Holambra, SP: Departamento de Qualidade e Pós-Colheita, 2013.5 p.

KIELING, A. S. et al. Plantas de cobertura de inverno em sistema de plantio direto de hortaliças sem herbicidas: efeitos sobre plantas espontâneas e na produção de tomate. Ciência Rural, 39: $2207-$ 2209, 2009.

LOSS, A. et al. Atributos físicos do solo em cultivo de cebola sob sistemas de plantio direto e preparo convencional. Revista Colombiana de Ciencias Hortícolas, 11: 105-113, 2017.

MATHEW, R. P. et al. Impact of No-Tillage and Conventional Tillage Systems on Soil Microbial Communities. Applied and Environmental Soil Science, 2012: 1-10, 2012.

NARESH, R. K. et al. Role of conservation agriculture for sustainable horticultural crop production through intercropping in North-West India. Annals of Horticulture, 6 : 82-92, 2013.

OUMA, G.; JERUTO, P. Sustainable horticultural crop production through intercropping: The case of fruits and vegetable crops: A review. Agriculture and Biology Journal of North America, 1: 1098-1105, 2010.

PIRES, L. F. et al. Soil structure changes induced by tillage systems. Soil \& Tillage Research, 165: 66-79, 2017.

SANTOS, H. G. et al. Sistema Brasileiro de Classificação de Solos. 5. ed. Brasília, DF: Embrapa, 2018. 356 p.

SCHWAB, N. T. et al. Parâmetros quantitativos de hastes florais de gladíolo conforme a data de plantio em ambiente subtropical. Pesquisa Agropecuária Brasileira, 50: 902-911, 2015.

SCHWAB, N. T. et al. Temperatura base para abertura de floretes e antocrono em gladíolo. Revista Ceres, 64: 557-560, 2017.

SCHWAB, N, T. et al. Duração do ciclo e danos por altas e baixas temperaturas em gladíolo em função da época de plantio. Ornamental Horticulture, 24: 163 $173,2018$.

SCHWAB, N. T. et al. Gladíolo: fenologia e manejo para produção de hastes e bulbos. 1. ed. Santa Maria, RS: Pallotti, 2019. 136 p.
SEVERINO, C. A. M. Cultivo comercial de Palma de Santa Rita (Gladiolus sp. Tourm.). 1. ed. Salvador, BA: SBRT, 2007. 22 p. (Dossiê técnico).

SOUZA, M. et al. Matéria seca de plantas de cobertura, produção de cebola e atributos químicos do solo em sistema plantio direto agroecológico. Ciência Rural, 43: 21-27, 2013.

STANCK, L. T. et al. Análises fenológicas de gladíolo em diferentes condições edafoclimáticas em Santa Catarina. Agrometeoros, 27:199-207, 2019.

THOMÉ, V. M. R. et al. Zoneamento Agroecológico e Socioeconômico de Santa Catarina. Florianópolis: Epagri, 1999. 1000 p. Disponível em: <https:// ciram.epagri.sc.gov.br/index.php/solucoes/ zoneamento/>. Acesso em: 05 dez. 2020.

TOMIOZZO, R. et al. Cycle duration and quality of gladiolus floral stems in three locations of Southern Brazil. Ornamental Horticulture, 24: 317-326, 2018.

TOMIOZZO, R. et al. How to produce gladiolus corms? Ornamental Hortculture, 25: 299-306, 2019.

UHLMANN, L. O. et al. PhenoGlad: A model for simulating development in Gladiolus. European Journal of Agronomy, 82: 33-49, 2017.

UHLMANN, L. O. et al. Gladiolus as an alternative for diversification and profit in small rural property. Ornamental Horticulture, 25: 200-208, 2019.

WANI, M. A. et al. Floriculture Sustainability Initiative: The Dawn of New Era. Sustainable Agriculture Reviews 27: 91-127, 2018. 